\title{
EFEKTIVITAS PEMBERIAN SEL UTUH (WHOLE CELL) BAKTERI VIBRIO TERHADAP PENINGKATAN KEKEBALAN TUBUH UDANG WINDU (Penaeus monodon FABR.) DARI SERANGAN WHITE SPOT SYNDROME VIRUS(WSSV)
}

\author{
Mun Imah Madeali", Muharijadi Atmomarsono"), dan Ahdiah Hamzah"')
}

\begin{abstract}
ABSTRAK
Penelitian ini bertujuan untuk mengetahui efektivitas penggunaan lipopolisakarida (bakterin) dan konsentrasi bakterin paling tepat yang dapat memberikan pengaruh terbaik terhadap peningkatan kekebalan tubuh serta sintasan benur windu dari serangan WSSV. Lipopolisakarida yang digunakan dalam penelitian ini adalah hasil ekstraksi dari bakteri Vibrio harveyi. Penelitian ini menggunakan rancangan acak lengkap (RAL) dengan empat perlakuan yaitu pemberian bakterin dengan konsentrasi $0 \mathrm{mg} / \mathrm{L}$ ( $A=$ kontrol), $20 \mathrm{~g} / \mathrm{kg}$ pakan (B), $30 \mathrm{~g} / \mathrm{kg}$ pakan (C), dan $40 \mathrm{~g} /$ kg pakan (D). Ulangan dilakukan sebanyak 3 kali untuk tiap perlakuan dan setiap ulangan menggunakan 80 ekor benur windu. Bakterin diberikan hanya sekali seminggu sebanyak delapan kali pemberian. Pada minggu ke-9, dilakukan uji tantang dengan menggunakan filtrat WSSV. Peubah yang diamati adalah sintasan, tingkat serangan WSSV, dan parameter kualitas air. Untuk mengetahui pengaruh perlakuan, data dianalisis dengan menggunakan metode analisis ragam (ANOVA) dan dilanjutkan dengan uji jarak berganda Duncan (DMRT). Hasil penelitian menunjukkan bahwa secara signifikan konsentrasi lipopolisakarida berpengaruh terhadap tingkat sintasan benur windu dan tingkat serangan WSSV. Konsentrasi lipopolisakarida $30 \mathrm{~g} / \mathrm{kg}$ pakan merupakan perlakuan terbaik dalam hal peningkatan sintasan benur windu dan mencegah invasi WSSV.
\end{abstract}

\begin{abstract}
The effectiveness of lipopolysaccharide on the improvement of immune response of tiger prawn (Penaeus monodon, Fabr.) against White Spot Syndrome Virus (WSSV) infection. By: Mun Imah Madeali, Muharijadi Atmomarsono, and Ahdiah Hamzah
\end{abstract}

The objectives of this research were to investigate the effect of lipopolysaccharide to stimulate immune response of tiger prawns against WSSV infection and to find out the proper dose of bacterin which is able to increase the immunity and survival rate of tiger prawns. The immunostimulant used in this research was the lipopopysaccharide (bacterin) extracted from Vibrio harveyi. Bacterin was incorporated with the prawns feed. Completely Randomized Design (CRD)was used with 4 treatments, i.e. $=0 \mathrm{~g} / \mathrm{kg}$ of feed (as control), 20,30, and $40 \mathrm{~g} / \mathrm{kg}$ of feed. Each treatment was done in three replicates and 80 tiger prawns were used per replicate. The bacterin was given once a week until 8 weeks. After week ninth the prawns were challenged with WSSV filtrate for up to 360 hours. The variables observed were the survival rate, the WSSV infection level and water quality. ANOVA was used for data analysis followed by Duncan'S New Multiple Range Test (DMRT). The research results revealed that bacterin concentration had a significant effect on the survival rate of the tiger prawns and on infection level of WSSV. The bacterin of $30 \mathrm{~g} / \mathrm{kg}$ of feed was the best concentration that was able to increase survival rate of the tiger prawns and to prevent the infection of WSSV.

KEYWORDS: lipopolysaccharide, immune, tiger prawn larvae, White Spot Syndrome Virus (WSSV)

\section{PENDAHULUAN}

Pada budi daya udang intensif, keberhasilan produksi sangat ditentukan oleh beberapa faktor antara lain ketersediaan benih, pakan, dan air yang bermutu baik, serta ada tidaknya penyakit. Penyakit merupakan salah satu kendala utama yang merugikan dalam produksi perikanan. Kerugian ini akan terus meningkat jika tidak ada upaya penanggulangannya. Penyakit terjadi akibat adanya interaksi antara inang yang lemah, patogen yang kuat, dan kualitas lingkungan yang menurun akibat berbagai bahan pencemar. 
Berbagai jenis penyakit yang biasa terjadi pada usaha pembenihan maupun pembesaran udang di tambak adalah vibriosis, kunang-kunang, MBV (Monodon Baculo Virus), WSBV (White Spot Baculo Virus) atau kini dikenal sebagai WSSV (White Spot Syndrome Virus), parasit dan jamur (Lightner, 1996; Atmomarsono et al., 1993; Tompo et al., 1993; Madeali et al., 1993; Madeali et al., 1998; Kasornchandra \& Boonyaratpalin, 1998; Atmomarsono, 2000). Bakteri Vibrio sp. di tambak dapat meningkat karena akumulasi sisa pakan (Atmomarsono \& Mansyur 1997). Sekitar US \$800 juta telah hilang per tahunnya dari seluruh areal pertambakan di Indonesia yang kini tinggal sekitar 368.000 ha akibat serangan penyakit dan penurunan mutu lingkungan (Atmomarsono et al., 2000).

Salah satu jenis penyakit yang menjadi masalah serius dalam budi daya udang windu di tambak adalah penyakit viral. Penyakit viral ini disebabkan oleh berbagai jenis virus. Owens et al. (1991) melaporkan sekitar 20 jenis udang penaeid telah diketahui terinfeksi virus. Di antara jenis virus yang sering menginfeksi udang penaeid adalah Systemic ectodermal and mesodermal baculo virus (SEMBV) atau biasa dikenal dengan nama White Spot Baculo Virus (WSBV) atau White Spot Syndrome Virus (WSSV) (Lo et al., 1996). Menurut Rajan et al. (2000), WSSV adalah salah satu jenis virus yang menyebabkan wabah penyakit, baik di panti pembenihan maupun di tambak, dan dapat menyebabkan kematian massal sampai $100 \%$ pada udang dalam waktu relatif singkat dengan tanda bintik putih pada karapas dan tubuh. WSSV pertama kali ditemukan pada tahun 1992 pada Penaeus japonicus yang dikultur di Taiwan (Chang et al., 1998). WSSV sangat patogenik pada $P$. indicus dan $P$. monodon (Hameed et al., 2000), sehingga dapat mengakibatkan mortalitas $100 \%$ dalam $2-7$ hari bila udang terinfeksi virus tersebut.

Virion SEMBV/WSSV berbentuk batang mempunyai amplop dan berukuran $266 \times 112 \mathrm{~nm}$ (Hameed et al., 2000). Bahan genetik virus ini berupa DNA rantai ganda yang berukuran lebih dari $150 \mathrm{kbp}$ (Lo et al., 1996). Karakteristik ini berdasarkan pada observasi histologi, mikroskop elektron, dan studi molekuler (Atmomarsono, 2000; Rajan et al., 2000).

Mengingat kerugian yang diakibatkan oleh penyakit viral ini sangat tinggi, perlu dipikirkan alternatif pencegahannya. Menurut Raa et al. (1992), salah satu cara penanggulangan penyakit adalah dengan immunoprofilaksis yaitu meningkatkan kekebalan udang terhadap serangan penyakit. Kekebalan terhadap penyakit dapat dipacu dengan pemberian immunostimulan.
Penanggulangan penyakit melalui penggunaan immunostimulan sangat cocok diterapkan pada udang, seperti diketahui bahwa udang hanya memiliki sistem pertahanan non spesifik yang bersifat sementara, sehingga diperlukan stimulasi yang berulang kali untuk mengaktifkan sistem immunnya. Rukyani et al. (1999) menyatakan bahwa immunostimulan merupakan sekelompok senyawa biologi dan sintetis yang dapat meningkatkan pertahanan nonspesifik. Oleh karena itu, immunostimulan dapat dijadikan sebagai alternatif terbaik dalam perlindungan terhadap serangan penyakit (Robertsen et al., 1990).

Salah satu immunostimulan potensial yang dapat mengaktivasi sistem pertahanan nonspesifik pada udang adalah lipopolisakarida (bakterin) yang berasal dari dinding sel bakteri gram negatif. Menurut Secombes (1994), penggunaan immunostimulan seperti b-Glucan dan Lipopolisakarida (bakterin) dapat meningkatkan daya pertahanan nonspesifik melalui peningkatan aktivitas fagositosis dari pertahanan seluler, sekurang-kurangnya meningkatkan aktivitas daya bunuh bakteri (bactericidal). Hal ini seperti yang dilaporkan oleh Rantetondok (2000), bahwa penggunaan immunostimulan bakterin yang diekstraksi dari bakteri Vibrio harveyi, kemudian dicampurkan melalui pakan dapat memacu sistem kekebalan udang windu untuk melawan invasi mikroorganisme patogen dari luar, khususnya hemosit yang terinduksi untuk melakukan fagositosis. Selanjutnya Takahashi et al. (2000) menggunakan immunostimulan bakterin yang diberikan per oral terbukti dapat meningkatkan aktivitas fagositosis dan aktivitas fenoloksidase (PO) pada hemosit udang.

\section{BAHAN DAN METODE}

\section{Persiapan}

Penelitian ini dilaksanakan selama \pm 5 bulan di Laboratorium Patologi Balai Riset Perikanan Budidaya Air Payau, Maros. Wadah yang digunakan adalah baskom plastik warna hitam berdiameter $60 \mathrm{~cm}$ dan tinggi $30 \mathrm{~cm}$ sebanyak 12 buah, yang diisi air laut sebanyak $10 \mathrm{~L}$ bersalinitas 27 ppt dan telah disucihamakan dengan kaporit $\left(\mathrm{Ca}(\mathrm{OCl})_{2}\right)$ serta dinetralisir dengan Natrium Tiosulfat $\left(\mathrm{Na}_{2} \mathrm{~S}_{2} \mathrm{O}_{3}\right)$. Untuk mempertahankan kelarutan oksigen maka setiap wadah dilengkapi dengan aerasi.

Hewan uji yang digunakan adalah benur udang windu PL-28 sebanyak 80 ekor/10 L air. Pakan yang digunakan adalah pakan komersil yang mempunyai nilai nutrisi protein $47 \%$, lemak $5 \%$, serat kasar $3 \%$, dan kadar air $11 \%$, diberikan dalam bentuk pelet yang digerus agar mudah dicerna oleh udang. Dosis pakan $50 \%$ per bobot biomassa/hari dengan frekuensi 
pemberian pakan 2 kali sehari yaitu pada pukul 07.00 dan 18.00. Pemberian pakan yang mengandung bakterin hanya diberikan 1 kali tiap minggu selama delapan minggu.

Perbanyakan populasi $V$. harveyidilakukan dengan mengambil koloni yang tumbuh pada media TCBSA yang telah diinkubasikan pada suhu $28^{\circ} \mathrm{C}$ selama 48 jam. Koloni bakteri $V$. harveyi diinokulasikan secara aseptik pada media NB yang mengandung $2 \% \mathrm{NaCl}$ dalam Erlenmeyer dengan bantuan shakerpada suhu ruangan selarna 48 jam. Untuk mengetahui kepadatan bakteri, maka dilakukan perhitungan jumlah sel bakteri pada media TCBS agar dan dihitung menggunakan formula Ganjar et al. (1992) dengan rumus:

$$
N=\frac{S \times T}{Q} \times V
$$

di mana:

$N$ = Jumlah bakteri (sel/mL)

$T=$ Total koloni bakteri pada semua plate dengan tingkat pengenceran yang sama

$S=$ Tingkat pengenceran

$V=$ Jumlah larutan yang digunakan $(\mathrm{mL})$

$Q=$ jumlah plate

Pembuatan bakterin dilakukan dengan cara mematikan biakan murni $V$. harveyidengan formalin $1 \%$ yang didiamkan selama 3 jam dalam tabung reaksi. Selanjutnya dicuci dengan saline solution $0,85 \%$ melalui sentrifuge dengan kecepatan $>5.000$ rpm selama 20 menit. Supernatan dibuang dan endapan dicuci kembali sampai 3 kali. Hasil ekstrak bakterin yang diperoleh ditimbang bobot basahnya dengan timbangan analitis sebanyak yang dibutuhkan sesuai konsentrasi perlakuan. Selanjutnya bakterin dicampur dengan pakan udang pada 3 konsentrasi masing-masing $20 \mathrm{~g} / \mathrm{kg}$ pakan, $30 \mathrm{~g} / \mathrm{kg}$ pakan, dan $40 \mathrm{~g} / \mathrm{kg}$ pakan. Bakterin dan pakan dicampur berdasarkan petunjuk Sung et al. (1997), yaitu mulamula pakan disemprot dengan larutan putih telur sampai merata sehingga pakan berubah warna dari keabu-abuan menjadi kehitam-hitaman. Kemudian bakterin dalam bentuk suspensi basah disemprotkan secara merata pada pelet tersebut dan terakhir dikering anginkan selama 24 jam.

\section{Prosedur Penelitian}

Penelitian ini dilakukan dalam beberapa tahapan yaitu:

\section{Persiapan hewan uji}

Benur yang berasal dari salah satu panti benih di Sulawesi Selatan diskreening dengan formalin $150 \mathrm{mg} /$
L selama 30 menit. Proses adaptasi dilakukan selama 10 hari yaitu dimulai dari umur PL-19 sampai PL-28.

\section{Pemberian pakan yang mengandung immunostimulan bakterin}

Hewan uji yang telah diadaptasikan, dipelihara dalam wadah yang telah disiapkan. Selanjutnya benur tersebut dirangsang kekebalannya melalui pemberian pakan yang mengandung immunostimulan bakterin pada hari pertama setiap minggu selama delapan minggu, dengan konsentrasi sesuai perlakuan dan pada hari-hari selanjutnya hanya diberi pakan biasa. Jumlah pakan yang diberikan adalah $50 \%$ per bobot biomassa/hari dan menurun sesuai umur udang. Sampling setiap minggu dilakukan untuk mengetahui bobot populasi udang yang akan menjadi acuan untuk menghitung jumlah pakan yang diberikan. Pengamatan terhadap pengaruh perlakuan dilakukan pada akhir pemberian bakterin yakni setelah delapan minggu.

\section{Uji tantang}

Untuk mengetahui efektivitas penambahan bakterin yang dilakukan selama delapan minggu terhadap perbaikan daya tahan tubuh benur, maka pada minggu kesembilan benur windu diuji tantang dengan menggunakan filtrat virus dengan konsentrasi L.C $C_{50}$ (konsentrasi virus yang mematikan $50 \%$ udang uji) sebanyak $12 \mathrm{~mL} . / 5 \mathrm{~L}$ air. Uji tantang dilakukan secara serentak pada setiap unit percobaan dengan cara perendaman selama 360 jam. Pengamatan terhadap tingkat serangan virus dan sintasan dilakukan setiap 24 jam sejak uji tantang.

\section{Rancangan Percobaan dan Analisis Data}

Rancangan penelitian digunakan Acak Lengkap yang terdiri atas 4 perlakuan dan 3 ulangan, sehingga terdapat 12 satuan percobaan (Steel \& Torrie, 1989; Gaspersz, 1991). Keempat perlakuan tersebut adalah penambahan lipopolisakarida pada pakan dengan dosis sebagai berikut:

Perlakuan:

\section{A : kontrol (tanpa lipopolisakarida) \\ B : lipopolisakarida $20 \mathrm{~g} / \mathrm{kg}$ pakan \\ C : lipopolisakarida $30 \mathrm{~g} / \mathrm{kg}$ pakan \\ D : lipopolisakarida $40 \mathrm{~g} / \mathrm{kg}$ pakan}

Penempatan wadah setiap unit percobaan dilakukan secara acak, karena lingkungan di dalam maupun di luar wadah percobaan dianggap homogen. Tata letak setiap wadah penelitian disusun dengan menggunakan tabel bilangan acak (Gaspersz, 1991) seperti berikut: 


\begin{tabular}{llll}
\hline A2 & B3 & C2 & D1 \\
B1 & C3 & A1 & D3 \\
D2 & C1 & B2 & A3 \\
\hline
\end{tabular}

Model analisis statistik yang digunakan untuk menganalisis data yaitu model linier additif seperti yang tertera pada persamaan berikut:

$$
Y_{i j}=m+a_{i}+e_{i j}
$$

di mana:

$Y_{i j}=$ Respon satuan percobaan yang menerima perlakuan immunostimulan ke-i pada ulangan ke-j

$m=$ Nilai tengah dari seluruh perlakuan (rata-rata umum)

$a_{1}=$ Pengaruh perlakuan immunostimulan ke-i

$e_{i j}=$ Pengaruh galat dari satuan percobaan yang menerima perlakuan immu- nostimulan ke-i pada ulangan ke-j

Data yang diperoleh sebelum dianalisis keragamannya dengan menggunakan analisis keragaman (ANOVA), terlebih dahulu ditransformasi ke arcus sinus (arcsin), untuk mendapatkan penyebaran data secara distribusi normal. Hasil yang diperoleh menunjukkan pengaruh nyata, maka dilanjutkan dengan uji beda rata-rata dengan menggunakan uji jarak berganda Duncan (DMNRT) (Gaspersz, 1991).

\section{Peubah yang Diamati dalam Penelitian ini Meliputi:}

\section{Sintasan}

Pengamatan terhadap sintasan (SR) dari udang uji dilakukan dengan perbandingan antara jumlah udang pada awal penelitian dan jumlah udang pada akhir penelitian, yang dapat dihitung berdasarkan petunjuk Effendie (1979) dengan rumus:

$$
\mathrm{SR}=\frac{\mathrm{Nt}}{\mathrm{No}_{0}} \times 100 \%
$$

di mana:

$\mathrm{SR}=$ Tingkat sintasan (\%)

$\mathrm{Nt}=$ Jumlah udang pada akhir penelitian (ekor)

No = Jumlah udang pada awal penelitian (ekor)

\section{Tingkat Serangan WSSV}

Untuk mengetahui tingkat serangan WSSV terhadap benur windu dilakukan dengan membandingkan persentase jumlah benur yang terinfeksi WSSV dan lama waktu pengamatan yang dapat dihitung berdasarkan Zonneveld et al. (1991) dengan rumus:

$\mathrm{Jml}$. benur yg mati karena infeksi/

Tk. Serangan $=\frac{\mathrm{jml} \text {. awal (individu) }}{\text { Waktu pengamatan }(j a m)} \times 100$

Selanjutnya dikonfirmasi dengan hasil analisis histopatologi dari jaringan hepatopankreas menggunakan pewarnaan Hematoxilyn dan Eosin. Kriteria yang dipakai untuk mendiagnosis penyakit adalah terjadi hypertrophy nucleiyang ditandai dengan adanya inclusion body pada jaringan organ yang dikoleksi. Hal ini merupakan ciri-ciri morfologis dari suatu jenis virus berdasarkan Lightner (1998) dan Rajan et al. (2000).

\section{Kualitas air}

Sebagai data penunjang dilakukan pengamatan terhadap parameter kualitas air yang meliputi suhu, $\mathrm{pH}$, salinitas, nitrat, nitrit, BOT pada awal, dan akhir penelitian.

\section{HASIL DAN BAHASAN}

\section{Tingkat Sintasan Benur Windu}

Pengaruh penambahan lipopolisakarida dalam pakan dapat diketahui dari respon sintasan benur windu sebelum dan sesudah uji tantang dengan WSSV. Tingkat sintasan benur windu setelah diberi perlakuan lipopolisakarida dengan konsentrasi yang berbeda selama delapan kali pemberian pada masing. masing periakuan disajikan pada Gambar 1.

Gambar 1 menunjukkan tingkat sintasan benur windu tertinggi didapatkan pada perlakuan $\mathrm{C}$ (bakterin $30 \mathrm{~g} / \mathrm{kg}$ pakan) sebesar $52,33 \% \pm 4,16$; disusul perlakuan B (bakterin $20 \mathrm{~g} / \mathrm{kg}$ pakan) sebesar $45,00 \%$ $\pm 5,00$. Sintasan benur windu terendah didapatkan pada perlakuan D (40 g/kg pakan) yakni sebesar $39,33 \% \pm 2,52$; disusul perlakuan A (tanpa bakterin) sebesar $41,67 \% \pm 4,62$. Hasil analisis ragam terlihat adanya pengaruh pemberian bakterin terhadap tingkat sintasan benur windu $(P<0,05)$ (Lampiran 1). Hasil uji lanjut dengan menggunakan uji berjarak Duncan (Lampiran 2) menunjukkan adanya perbedaan pengaruh yang nyata dari masing-masing perlakuan. Tingkat sintasan benur windu didapatkan sangat berbeda nyata $(P<0,01)$ antara perlakuan $C$ dengan perlakuan $A$ dan perlakuan $D$, tetapi antara perlakuan $C$ dengan perlakuan $B$ hanya memperlihatkan perbedaan yang nyata $(P<0,05)$, sedangkan antara perlakuan $A, B$, dan $D$ tidak menunjukkan adanya perbedaan. 


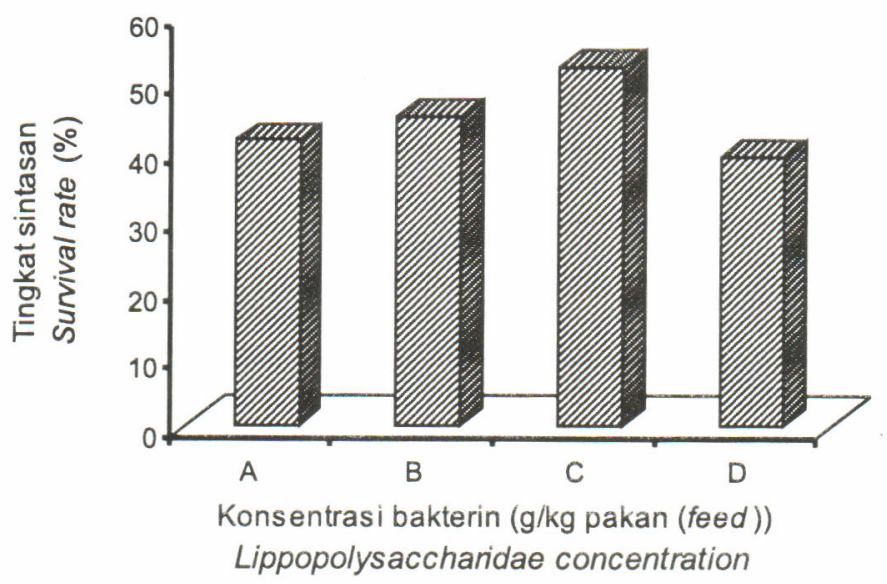

Gambar 1. Tingkat sintasan (\%) benur windu setelah delapan minggu pemberian pakan Figure 1. Survival rate (\%) of the tiger prawns larvae after 8 weeks feeding

Tingginya tingkat sintasan pada perlakuan $\mathrm{C}$ diduga merupakan dosis yang tepat dalam memberikan respon terbaik yang dibutuhkan benur windu untuk menginduksi sistem immun (kekebalan). Pada perlakuan B nilai sintasan benur windu lebih rendah dibanding perlakuan $\mathrm{C}$, hal ini diduga disebabkan oleh konsentrasi bakterin yang digunakan belum mencapai kadar yang dapat menginduksi sistem kekebalan. Menurut Tizard \& Ian (1988), pemberian immunostimulan dosis rendah akan menjadi immunosupresor. Dalam hal ini mekanisme kerja immunostimulan bakterin adalah menekan hemosit dalam mengaktivasi sel-sel fagosit.

Rendahnya nilai sintasan pada perlakuan D (bakterin $40 \mathrm{~g} / \mathrm{kg}$ pakan) diduga disebabkan oleh lebih dominannya sifat toksik dari bakterin tersebut. Jawetz et al. (1992) menyatakan bahwa bakterin sebenarnya merupakan endotoksin dan terdiri atas tiga bagian yaitu Lipid A, polisakarida inti, dan polisakarida-O (antigen o). Di antara ketiga bagian ini lipid $\mathrm{A}$ bersifat toksik sedangkan polisakarida-O merupakan antigen permukaan yang mampu menginduksi kekebalan. Menurut Kresno (1996), reaksi immunologi akan berlangsung tidak wajar atau berlebihan apabila jumlah antigen yang masuk ke dalam tubuh relatif tinggi, sehingga pada keadaan yang demikian lebih cenderung menimbulkan kerusakan jaringan.

Berdasarkan keterangan di atas, maka diduga sifat toksisitas lipopolisakarida dalam konsentrasi rendah dapat ditolerir tubuh benur windu dan yang bekerja adalah sifat immunogeniknya. Sebaliknya, bila konsentrasi tinggi dan masuk dalam tubuh akan terjadi in-efficient, dan kemungkinan akan menjadi immunostressor. Pada penelitian ini, meskipun perlakuan $\mathrm{C}$ diperoleh nilai rata-rata sintasan yang lebih tinggi dari ketiga perlakuan lainnya, namun secara umum dapat dilihat bahwa nilai sintasan pada semua perlakuan mengalami penurunan selama delapan minggu diberi perlakuan. Hal tersebut di atas disebabkan pertumbuhan udang yang semakin pesat sehingga mendorong terjadinya proses moulting. Pada kondisi demikian sifat kanibal akan turut mempengaruhi tingkat sintasan, sebab udang yang mengalami moulting kondisi tubuhnya sangat lemah sehingga dengan mudah akan menjadi mangsa oleh udang yang tidak mengalami moulting (Pascual, 1984).

Nilai sintasan pada perlakuan $\mathrm{C}$ sebelum uji tantang memperkuat nilai sintasan benur uji setelah ditantang dengan WSSV. Hasil pengamatan sintasan benur setelah uji tantang dengan filtrat WSSV selama 360 jam pada semua perlakuan disajikan pada Gambar 2.

Gambar 2 memperlihatkan perlakuan C pada 360 jam setelah diuji tantang dengan WSSV menunjukkan penurunan sintasan yang lebih rendah, kemudian menyusul perlakuan B. Penurunan sintasan tertinggi didapatkan pada perlakuan $D$ kemudian menyusul perlakuan A (tanpa bakterin).

Hasil analisis sidik ragam menunjukkan bahwa penambahan lipopolisakarida dalam pakan dengan konsentrasi yang berbeda berpengaruh sangat nyata $(\mathrm{P}<0,01)$ terhadap tingkat sintasan benur windu (Lampiran 3). Hal ini berarti bahwa perbedaan konsentrasi lipopolisakarida yang ditambahkan pada pakan memberikan nilai sintasan yang berbeda pada benur windu. Hasil uji berjarak Duncan (Lampiran 4) memperlihatkan perlakuan $C$ berbeda sangat nyata dengan ketiga perlakuan lainnya hingga akhir uji tantang. Sementara antara perlakuan A, B, dan D secara umum tidak menunjukkan perbedaan yang nyata.

Tingginya nilai sintasan pada perlakuan $\mathrm{C}$ diduga bahwa pada konsentrasi bakterin $30 \mathrm{~g} / \mathrm{kg}$ pakan telah 


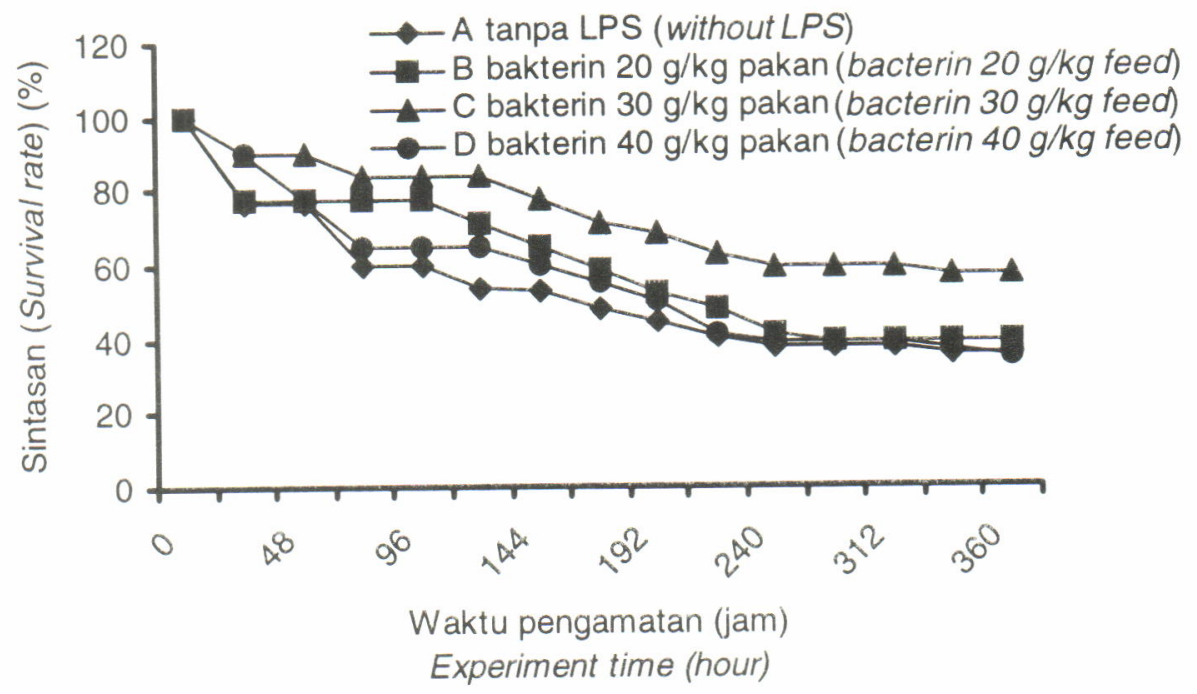

Gambar 2. Tingkat sintasan (\%) benur windu setelah uji tantang selama 360 jam

Figure 2. Survival rate (\%) of the tiger prawns larvae after 360 hours of challenged

dapat memacu sistem kekebalan tubuh benur windu untuk membentuk antibodi, sehingga dapat melawan invasi WSSV. Hal tersebut didukung hasil analisis secara histopatologi, di mana tidak didapatkan adanya kerusakan jaringan pada organ hepatopankreas benur windu yang terinfeksi WSSV. Dari hasil pengamatan secara visual juga tidak ditemukan adanya gejala klinis bahwa benur terinfeksi WSSV selama proses uji tantang berlangsung. Hal yang sama dilaporkan oleh Rantetondok (2000), melalui penambahan lipopolisakarida dalam pakan benur windu dengan konsentrasi $30 \mathrm{~g} / \mathrm{kg}$ pakan memperlihatkan nilai sintasan yang tertinggi $(100 \pm 0,00)$ setelah diuji tantang dengan bakteri $V$. harveyi selama 96 jam. Keadaan demikian menunjukkan bahwa penambahan lipopolisakarida dalam pakan dengan konsentrasi 30 $\mathrm{g} / \mathrm{kg}$ pakan, diduga merupakan dosis yang tepat untuk memacu pembentukan sistem kekebalan, khususnya kekebalan nonspesifik dalam hal ini sel-sel fagositik memegang peranan utama dan dikatakan sebagai mekanisme pertahanan seluler. Selain itu konsentrasi lipopolisakarida $30 \mathrm{~g} / \mathrm{kg}$ pakan yang diberikan sebanyak delapan kali dengan interval pemberian tujuh hari diduga sebagai waktu yang efektif dari lipopolisakarida dalam memacu sistem pertahanan seluler dalam tubuh benur windu. Sebagaimana dikatakan Ellis (1988) bahwa sel-sel ingatan pada eksposur kedua atau berulang dapat menghasilkan respon kekebalan sekunder, yaitu respon yang jauh lebih hebat dan lebih cepat dari respon promer terhadap produksi antibodi.

Hasil analisis regresi pengaruh konsentrasi lipopolisakarida terhadap tingkat sintasan benur windu memperlihatkan penambahan lipopolisakarida yang berbeda konsentrasi (X) menyebabkan respon sintasan benur windu $(Y)$ berpola kuadratik dengan persamaan $Y=49,716+1,2756 X-0,0266 X^{2}$ dengan nilai $R=0,73$. Hal ini memperlihatkan adanya kecenderungan rata-rata sintasan benur windu meningkat hingga batas optimum lipopolisakarida yakni sebesar 24,08 g/kg pakan.

\section{Tingkat Serangan WSSV terhadap Benur Windu}

Tingkat serangan WSSV terhadap benur uji dapat diketahui dari hasil pengamatan tingkat morbiditas, gejala klinis dan tingkah laku kemudian dikonfirmasikan dengan hasil analisis secara histopatologi.

Data tingkat serangan WSSV terhadap benur windu disajikan pada Tabel 1. Dari data tersebut diketahui tingkat serangan WSSV terhadap benur windu tertinggi didapatkan pada perlakuan A (tanpa bakterin) dengan nilai sebesar $10,93 \% \pm 0,73$. Tingkat serangan WSSV terendah didapatkan pada perlakuan C sebesar 6,62\% 0,00 .

Hasil analisis statistik (Tabel Lampiran 5) diperoleh bahwa penambahan lipopolisakarida dalam pakan memperlihatkan pengaruh yang sangat nyata terhadap pertahanan tubuh benur windu dari serangan WSSV. $\mathrm{Hal}$ ini menunjukkan bahwa perbedaan konsentrasi bakterin yang ditambahkan dalam pakan memberikan nilai tingkat serangan WSSV yang berbeda terhadap benur windu. Hasil uji lanjut berganda Duncan (Lampiran 5) diperoleh perlakuan $\mathrm{C}$ berbeda sangat nyata dengan ketiga perlakuan lainnya. Demikian pula antara perlakuan $B$ dan perlakuan $A$ menunjukkan perbedaan yang sangat nyata. Sementara antara perlakuan $B$ dan $D$ hanya menunjukkan perbedaan 
Tabel 1. Rata-rata jumlah (\%) benur windu yang terserang WSSV

Figure 1. Survival rate (\%) of the tiger prawns larvae after 8 weeks feeding

\begin{tabular}{lrrrrr}
\hline \multirow{2}{*}{$\begin{array}{c}\text { Ulangan } \\
\text { (Replicate) }\end{array}$} & \multicolumn{4}{c}{ Perlakuan (Treatment) } & \multirow{2}{*}{$\begin{array}{c}\text { Jumlah } \\
\text { (Total) }\end{array}$} \\
\cline { 2 - 5 } & $\mathbf{A}$ & \multicolumn{1}{c}{$\mathrm{B}$} & $\mathrm{C}$ & $\mathrm{D}$ & \\
\hline I & 11.78 & 8.57 & 6.62 & 10.07 & 37.04 \\
II & 10.51 & 8.57 & 6.62 & 11.09 & 36.79 \\
III & 10.51 & 10.07 & 6.62 & 10.47 & 37.67 \\
\hline Jumlah (Total) & 32.80 & 27.21 & 19.86 & 31.63 & 111.50 \\
\hline Rataan (Average) & 10.93 & 9.07 & 6.62 & 10.54 & 37.17 \\
\hline SD & 0.73 & 0.87 & 0.00 & 0.51 & 2.11 \\
\hline
\end{tabular}

nyata. Sedangkan antara perlakuan A dan D tidak menunjukkan adanya perbedaan.

Tingginya jumlah benur yang terserang WSSV pada perlakuan A diperkuat oleh analisis histologi. Dari hasil tersebut secara umum ditemukan jaringanjaringan tubuh benur windu mulai mengalami kerusakan pada pengamatan 72 jam, hal ini dapat dilihat pada Gambar 3.

Gambar 3A memperlihatkan kondisi rostrum yang mengalami pembengkakan pada inti (Hypertrophied nuclei). Gambar tersebut menunjukkan sel-sel sitoplasma masih tampak namun dikelilingi oleh partikel-partikel virus. Fenomena seperti ini menurut Rajan et al. (2000) merupakan stadia awal perkembangan virus, di mana didapati terjadinya Hypertrophied nuclei pada sel-sel epidermal bagian insang, kutikula epidermis, rostrum, stomach, hati, dan organ lymphoid. Pada pengamatan berikutnya WSSV semakin ganas menginfeksi jaringan tubuh benur, hal ini dapat diketahui dari jaringan-jaringan benur sampel yang memperlihatkan kondisi hepatopankreas yang sudah tidak normal lagi (Gambar 3B). Kerusakan ini didapatkan semakin parah hingga pengamatan terakhir.

Tingginya jumlah benur yang terserang WSSV pada perlakuan $\mathrm{A}$ disebabkan tidak terbentuk sistem pertahanan tubuh benur windu, karena tidak diberi lipopolisakarida yang dapat menstimulir pembentukan zat antibodi, sehingga saat diuji tantang dengan WSSV, benur windu dengan mudah terinfeksi.

Kondisi pada perlakuan A tidak jauh berbeda seperti yang terjadi pada perlakuan B. Pada perlakuan B sekalipun telah diberi lipopolisakarida namun jumlah benur yang terinfeksi WSSV masih agak tinggi yakni $9,07 \% \pm 0,87$. Dari hasil analisis histologi didapatkan jaringan-jaringan tubuh benur windu mulai mengalami kerusakan pada pengamatan 96 jam dan 216 jam, seperti terlihat pada Gambar 3C dan 3D.
Tingginya jumlah benur yang terinfeksi WSSV pada perlakuan B, diduga konsentrasi lipopolisakarida yang diberikan sebanyak $20 \mathrm{~g} / \mathrm{kg}$ pakan kurang efektif dalam menstimulir pertahanan seluler. Meskipun pada penelitian Rantetondok (2000) mengemukakan bahwa konsentrasi lipopolisakarida sebanyak $20 \mathrm{~g} / \mathrm{kg}$ pakan sudah mampu melawan infeksi bakteri $V$. harveyi selama 96 jam, namun pada penelitian ini konsentrasi lipopolisakarida sebanyak $20 \mathrm{~g} / \mathrm{kg}$ pakan belum mampu melawan invasi WSSV. Hal ini menunjukkan bahwa efektivitas lipopolisakarida berbeda dalam tubuh benur windu dalam mencegah perkembangan mikroorganisme patogen.

Secara umum pada perlakuan A, B, dan D diketahui dari hasil pengamatan secara visual terlihat pergerakan udang menjadi lambat, nafsu makan menurun, tubuh nampak membengkok, sering berada di pinggir wadah, kemudian diam atau membalikkan diri lalu diikuti oleh kematian. Kondisi udang yang dijelaskan demikian merupakan gejala klinis yang sering dijumpai pada udang yang terinfeksi WSSV seperti yang dikemukakan oleh Murwantoko et al. (1997) bahwa gejala serangan WSSV pada udang ditandai dengan menurunnya nafsu makan, udang banyak yang mengambang dan menepi ke pematang, kemudian diam dan terbalik lalu diikuti kematian.

\section{Kualitas Air}

Parameter kualitas air yang diukur pada penelitian ini adalah suhu, $\mathrm{pH}$, salinitas, nitrat, nitrit, dan BOT. Hasil pengukuran parameter kualitas air pada semua perlakuan selama penelitian disajikan pada Tabel 2 . Pada tabel tersebut dicantumkan pula nilai kualitas air media yang layak menurut pustaka.

Suhu air media pemeliharaan turut mempengaruhi respon kekebalan tubuh benur windu dan tingkat patogenesitas WSSV. Menurut Pasaribu (1993), proses pembentukan antibodi pada suhu rendah akan 

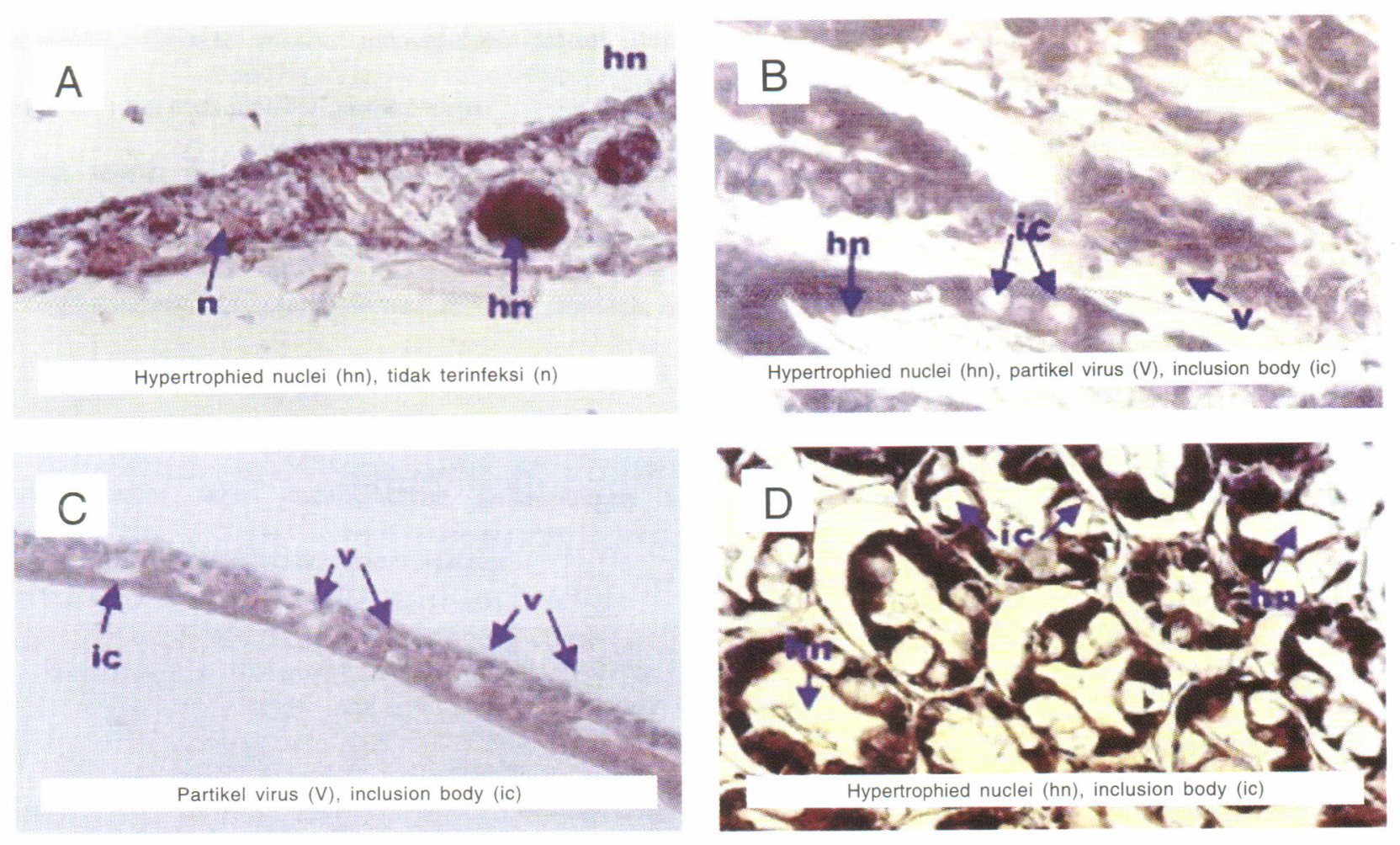

Gambar 3A. Foto mikrograf potongan longitudinal bagian rostrum benur windu setelah uji tantang pada pengamatan 72 jam

Figure 3A. Photograph of longitudinal section on rostrum of tiger prawn larvae after challenged test at 72 hours observation (400 X, H\& E)

Gambar 3B. Foto mikrograf potongan longitudinal hepatopancreas benur windu setelah uji tantang pada pengamatan 144 jam

Figure 3B. Photograph of longitudinal section on hepatopancreas of tiger prawn larvae after challenged test at 144 hours observation ( $400 X, H$ \& E)

Gambar 3C. Foto mikrograf potongan longitudinal kaki jalan benur windu setelah uji tantang pada pengamatan 96 jam

Figure 3C. Photograph of longitudinal section on pleopod of tiger prawn larvae after challenged test at 96 hours observation ( $400 X, H \& E)$

Gambar 3D. Foto mikrograf potongan longitudinal hepatopancreas benur windu setelah uji tantang pada pengamatan 216 jam

Figure 3D. Photograph of longitudinal section on hepatopancreas of tiger prawn larvae challenged test at 216 hours observation ( $400 X, H \& E)$

Tabel 2. Kisaran parameter kualitas air selama penelitian

Table 2. Range of water quality parameters

\begin{tabular}{lcc}
\hline \multirow{2}{*}{$\begin{array}{c}\text { Parameter } \\
\text { Parameters }\end{array}$} & \multicolumn{2}{c}{ Kisaran nilai berdasarkan (Value range basis) } \\
\cline { 2 - 3 } & $\begin{array}{c}\text { Hasil pengukuran } \\
\text { Measurement results }\end{array}$ & Pustaka (Publications) \\
\hline Suhu (Temperature) $\left({ }^{\circ} \mathrm{C}\right)$ & $28--29$ & $28--31$ (Poemomo, 1979) \\
pH & $7.38--8.43$ & $7.5--8.5$ (Wardoyo, 1975) \\
Salinitas $($ Salinity) $(\mathrm{ppt})$ & $27--32$ & $25--30$ (Wardoyo, 1975) \\
Nitrat (Nitrate) $(\mathrm{mg} / \mathrm{L})$ & $0.0520-0.0888$ & $<1.0$ (Pescod, 1973) \\
Nitrit (Nitrite) $(\mathrm{mg} / \mathrm{L})$ & $0.0356-0.0877$ & $<6.4$ (Cholik \& Poemomo, 1987) \\
BOT (TOM) & $1.264-16.432$ & $<50$ (Rukyani, 1993) \\
\hline
\end{tabular}


berhenti atau antibodi yang terbentuk sangat rendah. Suhu yang baik untuk pembentukan antibodi atau sistem kekebalan pada udang adalah sekitar $20^{\circ} \mathrm{C}-$ $32^{\circ} \mathrm{C}$ (Albores et al., 1996). Kondisi air media selama penelitian berkisar antara $28^{\circ} \mathrm{C}-32^{\circ} \mathrm{C}$ merupakan nilai kisaran yang sangat cocok bagi proses pembentukan kekebalan tubuh benur windu.

Menurut Wickins (1979), udang akan mengalami mortalitas yang tinggi jika $\mathrm{pH}$ air di bawah 5,0; sementara pada penelitian ini $\mathrm{pH}$ air media untuk semua perlakuan berkisar $7,38-8,43$. Nilai ini merupakan kisaran yang masih layak untuk kehidupan benur windu. Udang windu sebenarnya merupakan hewan yang bersifat euryhaline karena dapat menyesuaikan diri pada salinitas 3-45 ppt. Kadar salinitas yang didapatkan pada penelitian ini berkisar 27-32 ppt, kondisi salinitas semacam ini merupakan kisaran nilai yang sangat baik untuk kehidupan benur windu. Demikian pula nilai kisaran nitrit dan nitrat selama penelitian masih memenuhi persyaratan untuk pertumbuhan dan sintasan benur windu di mana menurut Pescod (1973), nitrat yang terbaik adalah tidak lebih dari $1,0 \mathrm{mg} / \mathrm{L}$.

Akumulasi bahan organik dalam jumlah yang sesuai dengan daya dukung lahan akan berdampak positif, karena dapat dihasilkan unsur-unsur hara yang dibutuhkan oleh organisme. Menurut Madeali at al. (1997), kandungan BOT 30-50 mg/L dapat meningkatkan populasi mikroorganisme patogen, udang mudah mengalami stres, nafsu makan berkurang, serta mudah terserang penyakit, sehingga mudah mengakibatkan kematian. Kadar BOT selama penelitian berkisar $1.390-16.432 \mathrm{mg} / \mathrm{L}$, masih berada di bawah kisaran bagi perkembangbiakan mikroorganisme patogen. Pada awal penelitian ini didapatkan nilai BOT lebih tinggi dibandingkan akhir penelitian. Hal ini disebabkan air laut sebagai media pemeliharaan kualitasnya secara fisik maupun kimiawi sudah mengalami penurunan, akibat limbah organik yang berasal dari limbah domestik, pabrik, dan pelabuhan. Penggunaan aerasi dan pergantian air merupakan salah satu upaya yang sering dilakukan para petani tambak dalam perbaikan mutu lingkungan habitat udang yang disebabkan oleh akumulasi bahan organik.

\section{KESIMPULAN}

1. Lipopolisakarida yang diekstrak dari bakteri $V$. harveyi dapat menstimulasi kekebalan tubuh benur windu terhadap serangan virus WSSV.

2. Konsentrasi lipopolisakarida $30 \mathrm{~g} / \mathrm{kg}$ pakan memberikan respon terbaik bagi sintasan benur windu.

3. Hasil analisis histopatologi menunjukkan bahwa konsentrasi lipopolisakarida $30 \mathrm{~g} / \mathrm{kg}$ pakan merupakan konsentrasi yang tepat dalam mencegah invasi WSSV.

4. Konsentrasi optimum lipopolisakarida adalah 24,08 g/kg pakan.

\section{DAFTAR PUSTAKA}

Albores, F.V., F.J. Vega, and K. Soderhall, 1996. A plasma protein isolated from brown shrimp (Penaeus californiensis) which enhanches the activation of prophenoloxidase sistem by b-1,3-Glucan. Developmental and Comparative Immunology, 20 (5): $299-306$.

Atmonarsono, M. 2000. Teknologi budidaya udang berkelanjutan. Balai Penelitian Perikanan Pantai, Maros, Makalah pada Konvensi Nasional II Pengelolaan Sumberdaya Pesisir dan Lautan Indonesia, Makassar 15-17 Mei 2000.

Atmomarsono, M. and A. Mansyur. 1997. Shrimp disease outbreak, a result of poor zonation in coastal area. In Noor, A. and A. Tahir (Eds.). Proceeding International Seminar on the sea and its environment. Hasanuddin Univ. Press. Ujung Pandang, p. 81-86.

Atmomarsono, M., M.I. Madeali, Muliani, dan A. Tompo. 1993. Kasus penyakit udang indu di Kabupaten Pinrang. Dalam Hanafi, A., M. Atmomarsono, dan S. Ismawati (Eds.). Prosiding Seminar Hasil Penelitian Perikanan Budidaya Pantai, Maros, 16-19 Juli 1993, p. $35-40$.

Chang, Poh-Shing, Hsiao-Chao Chen, and Yu-Chi Wang. 1998. Detection of white spot syndrome associated baculovirus in experimentally infected wild shrimp, crab and lobsters by in situ hybridization. Aquaculture, 164 (233-242).

Cholik, F. dan A. Poernomo. 1987. Pengelolaan mutu air tambak untuk budidaya udang intensif. Makalah Seminar Aeration di Medan. Balai Penelitian Budidaya Pantai, Maros.

Effendie, M.I. 1979. Metode Biologi Perikanan. Yayasan Dewi Sri, Bogor, 112 pp.

Ellis, A.E. 1988. Fish Vaccination. Academic Press, Aberdeen, 255 pp.

Ganjar, I., I.R. Koentjoro, W. Mangunwardoyo, dan L. Soebagya. 1992. Pedoman Praktikum Mikrobiologi Dasar. Fakultas MIPA-UI. Jakarta.

Gaspersz, V. 1991. Metode Perancangan Percobaan. Penerbit Armico, Bandung.

Hameed, A.S.S., M.X. Charles, and M. Anilkumar. 2000. Tolerance of Macrobrachium rosenbergii to White Spot Syndrome Virus. Aquaculture, (183): 207-213.

Jawetz, E.J., J.L. Melnik, and E.A. Adelberg. 1992. Review of Medical Microbiology. Ed. 14 (terjemahan). Lange Medical Publication, $846 \mathrm{pp}$.

Kasornchandra, J., and S. Boonyaratpalin. 1998. Primary shrimp cell culture: Application for studying White Spot Syndrome Virus (WSSV). In Flegel TW (Ed.) Advances in Shrimp Biotechnology. National center for genetic engineering and biotechnology, Bangkok, p. $273-276$. 
Kresno, B.S. 1996. Imunologi. Diagnosis dan Prosedur Laboratorium. Edisi III. Fakultas Kedokteran Universitas Indonesia, Jakarta.

Lightner, D.V. 1996. A Hand Book of Pathology and Diagnostic Procedures for Disease of Penaeid Shrimp. The World Aquaculture Society.

Lo, C.F., J.H. Leu, C.H. Chen, Y.L. Chiu, and C.F. Lo. 1996. Detection of baculovirus associated with White Spot Syndrome Virus (WSSV) in penaeid shrimps using polimerase chain reaction. Disease Aquatic Organism, 25: 133-141.

Madeali, M.I., M. Atmomarsono, Muliani, dan A. Tompo. 1997. Pengaruh konsentrasi BOT terhadap patogenesitas bakteri Vibrio sp. pada udang windu. Laporan Hasil Penelitian Perikanan Pantai, Maros.

Madeali, M.I., T. Arifuddin, dan Muliani. 1998. Diagnosis penyakit viral pada udang windu, Penaeus monodon secara Histopatologis dan Antibodi Poliklonal dengan metode ELISA. Jurnal Penelitian Perikanan Indonesia, Puslitbang Perikanan, Departemen Pertanian, Jakarta, 4 (3): 11-17.

Madeali, M.I., M. Atmomarsono, A. Tompo, dan Muliani. 1993. Studi kasus penyebab kematian udang windu, Penaeus monodon di tambak intensif. J. Pen. Budidaya Pantai, 9(4): 23-28.

Murwantoko, K., H. Nitimulyo, dan Simardiyono. 1997. Isolasi dan karakterisasi parsial biomolekuler systemic ectodermal dan mesodermal baculovirus (SEMBV) dari tambak di Kendal. Bioteknologi Program Pascasarjana Universitas Gajah Mada, Yogyakarta, 141-151.

Owens, L., S. De Beer, and J. Smith. 1991. Lyphoidal Parvovirus-like particles in Australian penaeid prawn. Dis. Aquatic Organism, 11: 129-134.

Pasaribu, F. 1993. Pelet Bervaksin terhadap Aeromonas hidrophyla. Fakultas Kedokteran Hewan, IPB, Bogor.

Pascual, F.D. 1984. Nutritional and Feeding of Sugfo ( $P$. monodon), $12 \mathrm{pp}$.

Pescod, M.B. 1973. Investigation of Rational Effluent and Stream Standard for Tropical Country. AIT. Bangkok.

Poernomo, A. 1979. Budidaya udang di tambak. Dalam Soegiarto, V.T. dan K.A.Goegiarto. Udang. Proyek penelitian potensi sumberdaya ekonomi, biologi, potensi, budidaya, produksi, dan udang sebagai bahan makanan di Indonesia. LON LIPI, Jakarta, p.71--124.

Raa, J., G. Roersted, R. Engstad, and B. Robertsen. 1992. The use of immunostimulant of increase resistanse of aquatic organism to microbial infections. Diseases in Asian Aquaculture I. Fish Health Section, Asian Society, Manila, Phillipines, 39-50.

Rajan, P.R., P. Ramasamy, Purushothaman, and G.P. Brennan. 2000. White spot baculovirus in the Indian shrimp, Penaeus monodon and Penaeus Indicus. J. Aquaculture, 184: 31-44.
Rantetondok, A. 2000. Pengaruh immunostimulan bglukan lipopolisakarida terhadap respon imun: letupan respurasi (Anion Superoksida) pada udang windu (Penaeus monodon Fabricus). Journal IImiah dan Teknologi Propgram Pasca sarjana Universitas Hasanuddin, Makassar, I(1).

Robertsen, B., G Roerstad, R. Engstad, and J. Raa. 1990. Enhachment of non-specific diseases resistance in Atlantic salmon (Salmo salar L.) by a glucan from Saccharomyces cerevisiae Cell-Wall. J. of Fish Diseases. p. 13-391.

Rukyani, A., E.E. Fitri, Taukhid, dan F. Pasaribu. 1999. Aplikasi imunostimulan lipopolisakarida dalam peningkatan tanggap kebal non spesifik ikan Botia macracantha terhadap penyakit bintik putih. Prosiding Seminar Hasil Penelitian Perikanan. Pusat Penelitian dan Pengembangan Eksplorasi Laut dan Perikanan, Jakarta, p. 198-206.

Rukyani, A. 1993. Penanggulangan penyakit udang windu Penaeus monodon. Dalam Hanafi, A., M. Atmomarsono, dan s. Ismawati (Eds.) Prosiding Seminar Hasil Penelitian Perikanan Perikanan Budidaya Pantai Maros, 6--19 Juli 1993, p: 1--8.

Secombes, C.J. 1994. Enhachment of fish pagocyte Activity. Fish and Shelfish Immunology, 4: 421-436.

Steel, R.G.D. and J.H. Torrie. 1989. Principles and Procedure of Statistic a Biometrical Approach. Second Edition. MC Graw Hill International Book Company, New York.

Sung, H.H., H.J. Chang, C.H. Her, J.C. Chang, and Y.L. Song. 1997. Phenoloxidase activity of hemocytes derived from Penaeus monodon and Macrobrachium rosenbergii. Invertebrate Pathology, 71: 26-33.

Takahashi, Y., M. Kondo, T. Itami, T. Honda, H. Inagawa, T. Nishizawa, G. Soma, and Y. Yokomizho. 2000. Enhancement of disease resistance against penaeid acute viremia and induction of virus-inactivating activity in hemolimph of Kuruma shrimp, Penaeus japonicus, by Oral Administration of Pantoea Agglomerans Lipopolysaccharide (bakterin). Fish and Shelfish Immunology.

Tizard and R.Ian. 1988. An Introduction to Veterinary Immunology (Terjemahan: Partodirejo, M. e al.). Erlangga University Press, Surabaya.

Wardoyo, S.T.H. 1975. Kriteria Kualitas Air untuk Keperluan Pertanian dan Perikanan. Institut Pertanian Bogor.

Wickins, J.F. 1979. The effect of reduce $\mathrm{pH}$ on carapace calcium, strontium and magnesium levels in rapidly growing prawns. Penaeus monodon Fabricius. Aquaculture, 41: 49-60.

Zonneveld, N., E.A. Huisman, dan J.H. Boar. 1991. Prinsip-Prinsip Budidaya Ikan. Gramedia Pustaka Utama, Jakarta. 
Lampiran 1. Analisis ragam sintasan benur windu setelah diberi pakan yang mengandung lipopolisakarida Attachment 1. Analysis of tiger prawn survival rate diversity after being fed containing lippopolysaccharidae

\begin{tabular}{|c|c|c|c|c|c|c|}
\hline \multirow{2}{*}{$\begin{array}{c}\text { Sumber keragaman } \\
\text { Diversity sources }\end{array}$} & \multirow{2}{*}{ DB } & \multirow{2}{*}{ JK } & \multirow{2}{*}{ KT } & \multirow{2}{*}{$\begin{array}{l}\text { F. Hitung } \\
\text { Compute }\end{array}$} & \multicolumn{2}{|c|}{ F. Tabel (Table) } \\
\hline & & & & & 0.05 & 0.01 \\
\hline Rataan (Average) & 1 & $23,852.08$ & $23,852.08$ & & & \\
\hline Perlakuan (Treatment) & 3 & 288.92 & 96.31 & $5.503^{\star}$ & 4.26 & 7.59 \\
\hline Error (Error) & 8 & 140.00 & 17.5 & & & \\
\hline Jumlah (Total) & 112 & $24,281.00$ & & & & \\
\hline
\end{tabular}

Keterangan (Note):

* Berpengaruh nyata $(P<0,05)$

Significantly affected $(P<0.05)$ 
M.I. Madeali, Atmomarsono, M., dan Hamzah, A.

Lampiran 2. Hasil uji berjarak duncan tingkat sintasan benur windu setelah diberi pakan yang mengandung lipopolisakarida

Attachment 2. Results of duncan distanced test of tiger shrimp larvae survival rate after being feed containing lippopolysaccharidae

\begin{tabular}{lc}
\hline Perlakuan (Treatment) & Nilai Rataan (\%) (Average value) \\
\hline C (bakterin (bacterin) $30 \mathrm{~g} / \mathrm{kg}$ pakan (feed)) & $52.33 \pm 4.16^{\mathrm{ab}}$ \\
B (bakterin (bacterin) $20 \mathrm{~g} / \mathrm{kg}$ pakan (feed)) & $45.00 \pm 5.00^{\mathrm{bc}}$ \\
A (tanpa bakterin (without bacterin) & $41.67 \pm 4.62^{\mathrm{C}}$ \\
D (bakterin (bacterin) $40 \mathrm{~g} / \mathrm{kg}$ pakan (feed)) & $39.33 \pm 2.52^{\mathrm{C}}$ \\
\hline
\end{tabular}

Keterangan : Angka yang diikuti huruf yang berbeda pada kolom yang sama menunjukkan perbedaan yang sangat nyata

Note: Number followed by different alphabet on the same column show the significant differences 